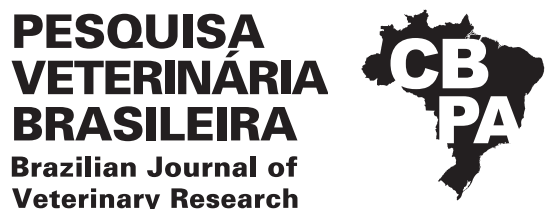

Pesq. Vet. Bras. 41:e06915, 2021

DOI: 10.1590/1678-5150-PVB-6915

Original Article

Livestock Diseases

ISSN 0100-736X (Print)

ISSN 1678-5150 (Online)

\title{
Ocular and oral lesions caused by Tacinga inamoena in sheep and goats in Northeast Brazil ${ }^{1}$
}

\author{
Walter H.C. Pequeno ${ }^{2 *}\left(\mathbb{D}\right.$, Rômulo F.F. $\operatorname{Dias}^{2}$ D, Alexandra M. Oliveira $^{3}$, \\ Lucas C. Dutra ${ }^{2}$, Ivia C. Talieri ${ }^{4}$, Ricardo B. Lucena² ${ }^{2}$ (D) and Sara V.D. Simões ${ }^{2}$
}

\begin{abstract}
Pequeno W.H.C., Dias R.F.F., Oliveira A.M., Dutra L.C., Talieri I.C., Lucena R.B. \& Simões S.V.D. 2021. Ocular and oral lesions caused by Tacinga inamoena in sheep and goats in Northeast Brazil. Pesquisa Veterinária Brasileira 41:e06915, 2021. Graduate Program in Animal Science, Centro de Ciências Agrárias, Universidade Federal da Paraíba, Rodovia PB-079, Areia, PB 58397-000, Brazil. E-mail: walterpequeno@hotmail.com

Two outbreaks of traumatic injuries in goats and sheep associated with grazing and ingestion of the cactus Tacinga inamoena have recently been reported in the state of Paraíba, Brazil. In the first of these, which was detected in 2019 during a preliminary inspection of a herd of 70 animals, it was found that 15 showed certain ocular complications, and these animals were subjected to general physical and ophthalmic examinations. The clinical findings included excessive lacrimation, blepharitis, photophobia, corneal opacity, hyphema, corneal neovascularization, corneal ulcers, and adherence of gloquids to the bulbar conjunctiva and cornea. Large amounts of T. inamoena were found to be present in several areas in which these animals had been grazed and had been observed consuming the fruits of this plant. In the second outbreak during the following year, two sheep from a total of 100 animals were identified as having oral lesions associated with grazing in areas within which T. inamoena was growing. One of these animals was referred to a veterinary hospital, and on physical examination was found to show apathy, anorexia, a body score of 1.5 , and the presence of gloquids within the fur. With respect to the oral cavity, halitosis, severe sialorrhea, extensive hemorrhagic ulcers, and painful tenderness on palpation were detected. Given the unfavorable prognosis, the sheep was subsequently euthanized. At necropsy, multifocal to coalescent plaques were detected on the upper and lower lips, oral mucosa, tongue, and hard and soft palates. These were generally elevated and firm and characterized by an irregular, ulcerated surface, sometimes crusty, with a yellow to light brown center and erythematous edges. The findings of this study highlight that the consumption of T. inamoena can cause serious oral and ophthalmic lesions in small ruminants in the northeastern semi-arid regions of Brazil, and can potentially contribute to substantial large economic losses. This problem tends to be exacerbated by the invasive behavior of T. Inamoena, particularly in areas in the process of environmental degradation.
\end{abstract}

INDEX TERMS: Ocular lesions, oral lesions, Tacinga inamoena, sheep, goats, Brazil, ovine, caprine, ruminant, traumatic condition, keratoconjunctivitis, stomatitis, cactus.

RESUMO.- [Lesões oculares e orais causadas por Tacinga inamoena em ovinos e caprinos no Nordeste brasileiro.]

\footnotetext{
${ }^{1}$ Received on May 22, 2021.

Accepted for publication on June 7, 2021.

${ }^{2}$ Graduate Program in Animal Science, Centro de Ciências Agrárias (CCA), Universidade Federal da Paraíba (UFPB), Rodovia PB-079, Areia, PB 58397 000, Brazil. *Correponding author: walterpequeno@hotmail.com

${ }^{3}$ Graduate Program in Veterinary Medicine, Universidade Federal de Campina Grande (UFCG), Centro de Saúde e Tecnologia Rural (CSTR), Avenida Universitária s/n, Bairro Santa Cecília, Patos, PB 58708-110, Brazil.

${ }^{4}$ Veterinary Hospital, Universidade Federal da Paraíba (UFPB), Areia, PB 58397-000, Brazil.
}

Relatam-se dois surtos de lesões traumáticas associadas ao pastejo e ingestão da Tacinga inamoena por caprinos e ovinos no estado da Paraíba, Brasil. No primeiro surto observou-se durante uma inspeção preliminar do rebanho que 15 dos 70 animais apresentavam alterações oculares, os animais foram submetidos ao exame físico geral e ao exame oftálmico. Lacrimejamento excessivo, blefarite, fotofobia, opacidade de córnea, hifema, neovascularização corneana, úlceras de córnea e gloquídeos aderidos à conjuntiva bulbar e córnea foram os achados clínicos identificados. A planta estava presente em diversas áreas e em grande quantidade nas áreas de pastejo, onde os animais eram vistos ingerindo 
seus frutos. No segundo surto, dois ovinos de um total de 100 animais, foram identificados com lesões orais associadas ao pastejo em áreas da planta. Um deles foi encaminhado ao Hospital Veterinário. No exame físico, o animal apresentou apatia, anorexia, escore corporal 1,5, pelos opacos, eriçados e no pelame era possível identificar gloquídeos. Na cavidade oral observou-se halitose, sialorreia intensa, extensas úlceras hemorrágicas e sensibilidade dolorosa à palpação. Devido ao prognóstico desfavorável o animal foi eutanasiado. $\mathrm{Na}$ necropsia, placas multifocais a coalescentes, elevadas, firmes e com superfície irregular, ulcerada, por vezes crostosas, com centro amarelo a marrom-claro e bordos eritematosos, estavam presentes nos lábios superiores, inferiores, mucosa oral, língua, palatos duro e mole. T. inamoena causa sérias lesões orais e oftálmicas em pequenos ruminantes no semiárido nordestino e prejuízos econômicos de grandes dimensões, que podem ser agravados pelo comportamento invasor da $T$. inamoena em áreas com indícios de degradação ambiental.

TERMOS DE INDEXAÇÃO: Lesões oculares, lesões orais, Tacinga inamoena, ovinos, caprinos, Brasil, ruminantes, afecções traumáticas, ceratoconjuntivite, estomatite, cactáceas.

\section{INTRODUCTION}

The Northeast region of Brazil is home to a large number of species in the Cactaceae family of cacti, and under conditions in which suitable sources of forage are scarce, notably during periods of drought, it is common practice to use these cacti as a feed for animals, including goats and sheep (Lucena et al. 2012). However, few of these species have been well studied, and the potentially harmful effects of their consumption on animal health have yet to be ascertained.

The cactaceous genus Tacinga is endemic to the semiarid regions of Brazil. These cacti are widely distributed in the Northeast region, and also occur in the north of Minas Gerais state and in areas of the Brazilian Cerrado (Souza et al. 2007, Zappi et al. 2015). The term Tacinga is a modification of "Caatinga," a region in which these cacti are abundant and well distributed. Tacinga inamoena, a species commonly referred to as combeba, gogóia, or quipá, is a shrubby plant growing to heights of between 20 and $100 \mathrm{~cm}$. The stems comprise elliptical to oval articles, measuring $8.0-9.0 \mathrm{~cm}$ long $\mathrm{x} 4.5-5.5 \mathrm{~cm}$ wide $\mathrm{x}$ $1.0-1.2 \mathrm{~cm}$ thick, and although irregularly arranged, they tend to have an elegant overall appearance. The entire vegetative body of the plant is green to slightly grayish in color and bears orange, diurnal, sessile flowers of $4-5 \mathrm{~cm}$ in diameter, which are produced at the apex of the terminal cladodes. The fruit is a berry ranging in color from yellow to orange and have an ovoid to subglobose shape approximately 3.0 to $4.0 \mathrm{~cm}$ long and 2.4 to $3.5 \mathrm{~cm}$ wide. Within, the light peach-colored flesh is funicular to translucent and there are numerous brownish seeds (Andrade 1989, Taylor \& Zappi 2004).

Although these plants lack spines, they do produce numerous tufts of gloquids, which are small sharp structures of almost crystalline cellulose. These "micro-spines" represent a particular hazard to livestock, as they are readily detached and can cause intense irritation if they happen to penetrate the skin or mucous membranes, from which they are difficult to remove. The fruits and cladodes of this plant are, nevertheless, often used in rural areas as a source of animal feed (Andrade 1989, Taylor \& Zappi 2004, Coelho et al. 2020).
In this study, we describe two outbreaks of traumatic injuries associated with the grazing and ingestion of T. inamoena by goats and sheep in Paraíba State, Brazil.

\section{MATERIALS AND METHODS}

Details relating to the history, epidemiological data, and clinical aspects of the outbreaks were obtained during visits to two properties at which the respective outbreaks were reported: one located in the municipality of Pocinhos and the other in Barra de Santa Rosa, Paraíba State, which are separated by a distance of $78 \mathrm{~km}$. At both these properties, livestock were maintained in areas in which Tacinga inamoena was relatively abundant, owing to an absence of other sources of forage and suitable areas for grazing.

In both instances, the affected animals underwent general physical and ophthalmic examinations, as the main complaints described by the owners were eye irritation. The ophthalmic examination consisted of inspection of the eye bulb and ocular appendages with the aid of a magnifying glass $(\times 3)$ and flashlight, threat test, pupillary reflex to light, applanation tonometry, and fluorescein dye staining.

During visits to the outbreak locations, we collected plant specimens for taxonomic identification. These were pressed and dried, and have been deposited in the Jayme Coelho de Morais Herbarium at the "Universidade Federal da Paraíba" (UFPB), under reference number No. 29.080, for botanical identification.

One sheep with eye lesions identified at the Pocinhos location, and another from the Barra de Santa Rosa location with oral lesions and extreme weakness, were referred to the Veterinary Hospital of UFPB for clinical follow-up, at which blood count, serum biochemical evaluation (aspartate aminotransferase activity - AST, gamma glutamyltransferase - GGT, albumin, creatinine, urea), urinalysis, and fecal parasitology examination were performed on request. Given the severe nature of the clinical symptoms and unfavorable prognoses, the debilitated animals were euthanized. The remaining animals with ophthalmic lesions received appropriate therapy and were subsequently reintroduced to their respective herds.

Euthanasia was was performed using xylazine $(0.2 \mathrm{mg} / \mathrm{kg} / \mathrm{IM})$ followed by thiopental $(15 \mathrm{mg} / \mathrm{kg} / \mathrm{IV})$. Having confirmed unconsciousness and loss of corneal reflex, potassium chloride (100mg/kg/IV) was administered. Necropsy was performed using the conventional technique. Samples of all organs were fixed in 10\% buffered formalin, embedded in paraffin, cut at $4 \mu \mathrm{m}$, and stained with hematoxylin and eosin (HE), followed by histopathological evaluation.

\section{RESULTS}

The first of the two outbreaks reported herein occurred in November 2019 on a property in the municipality of Pocinhos, where a combined herd of 70 goats and sheep are raised extensively. The owner reported that the animals had been suffering from serious eye complications for at least the previous 5 years. These problems were observed throughout the year, although tended to be more evident during the dry season (September to January). On the owner's initiative, the animals had already received treatment with antibiotics and anti-inflammatory drugs used for eye diseases, although without therapeutic success. In addition to eye problems, some animals were characterized by excessive salivation and difficulty in feeding, on account of lesions within the oral cavity.

A preliminary inspection of the herd revealed that 15 of the 70 animals (21.4\%) had ocular alterations, and in one male goat, a breeder, oral lesions were identified (Fig.1). During the physical examination of these animals, numerous micro- 

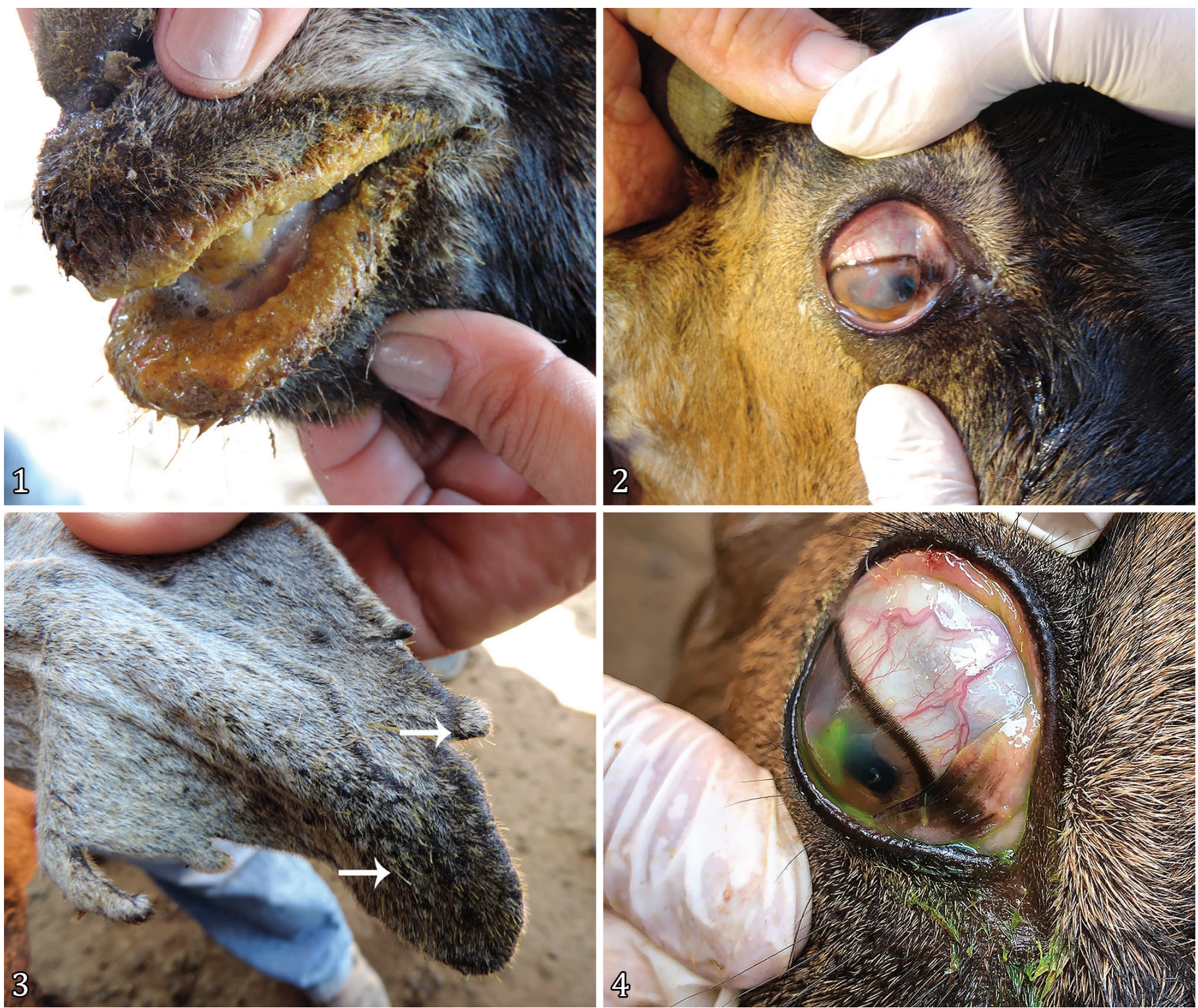

Fig.1-4. Oral, ocular, and auricular lesions in goats associated with the ingestion of Tacinga inamoena. (1) Sharp diffuse ulcerative cheilitis covered by suppurative exudate. (2) Hyperemic bulbar conjunctiva, epiphora, corneal neovascularization, and corneal edema. (3) Gloquids embedded in the skin of the auricular pinna (white arrows). (4) Ulcerative keratitis verified by fluorescein dye staining.

spines, which were later identified as the gloquids of Tacinga inamoena, were detected in the facial, palpebral, conjunctival (Fig.2), and auricular (Fig.3) regions.

Excessive lacrimation, blepharitis, photophobia, corneal opacity, hyphema, corneal neovascularization, and corneal ulcers, verified based on fluorescein staining (Fig.2 and 4), were the clinical signs and lesions identified in animals with a history of ocular alterations. Observations performed with the aid of a magnifying glass enabled us to detect gloquids adhering to the bulbar conjunctiva and cornea. Those goats with oral lesions were characterized by sialorrhea, difficulty in grazing food, halitosis, and ulcers in the gingival and lingual regions, and several gloquids were observed in the center of the ulcerated regions.

An inspection of the areas in which the animals were grazed revealed the presence of large quantities of $T$. inamoena in several areas (Fig.5), and according to the owner, animals were often seen feeding on the fruit of this plant.
The animals showing evidence of ulcerative keratitis were prescribed a single drop of tobramycin ${ }^{5}$ sulfate-based eye drops at 6-h intervals for 7 days or until the ulcers had healed. The animals with oral lesions were fed with tender, good-quality forage, and removed from the sites colonized by $T$. inamoena.

The animal referred to the Veterinary Hospital with ophthalmic lesions received treatment similar to that conducted at the property. After the treatment, the goat with corneal edema that was treated with eye drops based on dexamethasone $0.1 \%{ }^{6}$, with a single drop being administered at 12 -h intervals for 14 days, and after clinical improvement, was reintroduced to the herd.

\footnotetext{
Tobrasyn $^{\circledR}$, tobramycin sulfate, Syntec.

6 Maxidex $^{\circledR}$, dexamethasone, Alcon.
} 


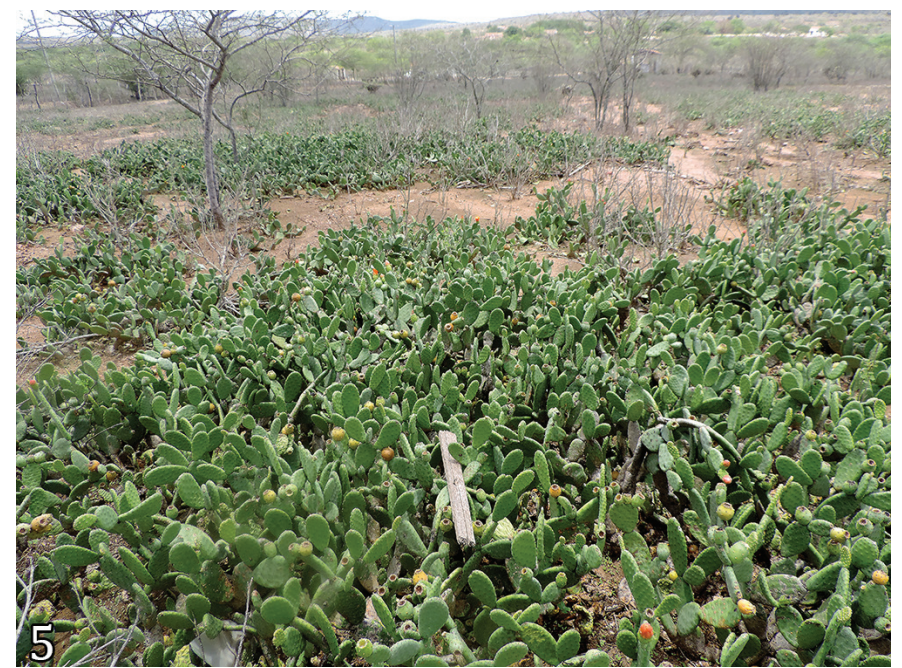

Fig.5. Livestock grazing areas where Tacinga inamoena is present in large numbers.

The second outbreak reported in this study occurred in March 2020 on a property in the municipality of Barra de Santa Rosa, where approximately 100 animals, both goats and sheep, are raised extensively. For several years, the owner had reported that the sheep were regularly suffering from sores and that these animals were typically characterized by an unpleasant odor emanating from the mouth, with some eventually succumbing to their symptoms, owing to an inability to feed themselves. As in the first outbreak, detection of the most severe cases coincided with the dry season.

At the time of our visit to this premises, two sheep were diagnosed with oral lesions, one of which, a female of approximately two years of age and of undefined breed, was referred to the Veterinary Hospital of UFPB. On physical examination, the animal was found to show evidence of apathy and anorexia, had a body score of 1.5 , and opaque rough hair, Moreover, T. inamoena gloquids were detected throughout the coat. Examination of the oral cavity revealed halitosis, intense sialorrhea, extensive hemorrhagic ulcers, and a painful tenderness on palpation. Notably, several gloquids were identified on the dorsal region of the tongue, inner cheek, and upper and lower gums.

Hematological examination revealed microcytic and hypochromic anemia (hematimetry $6.70 \times 10^{12} / \mathrm{L}$; hemoglobin $53 \mathrm{~g} / \mathrm{L}$, and globular volume $20 \%$ ), and analysis of blood biochemistry indicated hypoalbuminemia (20.3g/L) and reduced levels of urea $(22 \mathrm{mg} / \mathrm{dL})$. Furthermore, stool parasitology, revealed the presence of a species of nematode in the superfamily Tricostrongyloidea (4300 eggs per gram).

Given the severity of the symptoms identified based clinical and laboratory analyses and the generally unfavorable prognosis, euthanasia was performed. At necropsy, ulcerated papular lesions associated with ulcers and erosions were identified in the upper and lower lips, oral mucosa, tongue, and hard and soft palates. These were coalescing, elevated, firm, and with an irregular surface, and were covered by necrotic remains, varying from yellow to light brown in color and with erythematous borders (Fig.6-9). Moreover, aciculiform millimeter-sized plant material was noted throughout the lesioned and adjacent areas. The macro-aspect of lesions of the oral cavity mucosa was characterized as erosive and ulcerative diphtheric stomatitis. Plant material was also observed in the auricular region, although was not associated with lesions.

Histopathological examination revealed ulcerative lesions at the mucocutaneous junction (lip) that had destroyed the epidermis. The superficial and deep dermis were observed to be expanded and elevated, and there was infiltration throughout the deeper layers of the muscle layer. The lesions were characterized by severe, multifocal to coalescing inflammatory infiltrates, with large numbers of epithelioid macrophages, intact and degenerating neutrophils. Smaller numbers of eosinophils and plasma cells were also present, surrounding fragments of plant material, which had visible lance-shaped spinous projections (Fig.10-11). The superficial epithelium adjacent to lesions was irregular and thickened (acanthosis), with multifocal pustules in the horny layer of the epidermis, whereas eosinophilic degeneration of collagen fibers was detected in the superficial and deep dermis.

On the oral mucosa (gingiva), hard palate, and upper surface of the tongue, there were ulcerative lesions that had destroyed the mucosa and caused an expansion and elevation of the submucosa, along with infiltration into the deeper layers of muscle bundles. This latter feature was characterized by severe, multifocal to coalescing inflammatory infiltrates comprising a large number of epithelioid macrophages, intact and degenerate neutrophils, and smaller numbers of eosinophils and plasma cells surrounding fragments of plant material. Moreover, the superficial epithelium adjacent to the lesion was irregular and thickened (acanthosis), with multifocal pustules in the horny layer.

\section{DISCUSSION}

The epidemiological data, clinical signs, and pathological findings obtained for animals affected in the two outbreaks of ocular and oral lesions substantiate the involvement of Tacinga inamoena. The level of morbidity $(21.4 \%)$ recorded for the herd grazed in the municipality of Pocinhos serves to highlight that this problem can represent a source of significant economic losses, owing to the reduced weight of affected animals and the necessary medication costs. However, the ultra-extensive farming regime under which the Barra de Santa Rosa herd is grazed would make it extremely difficult to calculate the morbidity and lethality in the herd, given that the number of animals, the number of affected animals, and deaths had not been specified. The owner did, nevertheless, mention that numerous animals had become ill and subsequently died.

In the case of the two necropsied animals, there was no evidence to indicate the migration of T. inamoena gloquids to any of the internal organs, despite their spear shape, as this feature would tend to prevent retrograde movement. Thus, it would appear that these foreign bodies caused chronic inflammation only at those sites at which there was direct contact. In this regard, however, the findings of several studies have indicated that subsequent to chewing, the migration of plant stems can cause lesions, such as arteritis, meningoencephalitis, and uveitis (Sorden \& Radostits 1996); abscesses in the central nervous system (Linon et al. 2014); suppurative parotitis (Sinopidis et al. 2011); and pancreatitis and peritonitis (Citi et al. 2017).

The severe lesions identified in the oral cavity, including the tongue, would explain the anorexia, weight loss, and 
weakness reported by the owners, which if left untreated would eventually prove fatal. The hematological and biochemical changes detected in the affected animals reported herein are consistent with the extreme cachexia identified in necropsied animals. The invasiveness and extension of the lesions, caused by the gloquids, are indicative of the severity of this problem and would tend to suggest the successive contact between grazing animals and T. inamoena.

The clinical signs shown by animals with oral lesions have also been reported in domestic dogs and cats after licking and chewing Arctium lappa L., a plant that, when dried or dead, can adhere to the fur. These animals may thus inadvertently take in plant fragments during bouts of fur cleaning, thereby leading to lesioning associated with the fibrous granulation of tissue (Thiverge 1973).
Outbreaks of lesions of the type reported herein can generally be attributed to the herd behavior of ruminants and the local characteristics of the properties studied, where there are large areas invaded by T. inamoena, which may be the only food source available for animals at the time these outbreaks were reported. Outbreaks of oral lesions associated with the ingestion of plant material have also been described in horses and cattle. For example, following the ingestion of Setaria geniculata, horses in the United States were found to show mild clinical signs of gingivitis (Turnquist et al. 2001), whereas in Australia, it has been reported that a cow developed severe oral lesions after ingestion of material from a local haystack, which was associated with the development of ulcers, anorexia, apathy, and salivation, and on the same property, 20 horses also developed oral ulcers (McCosker
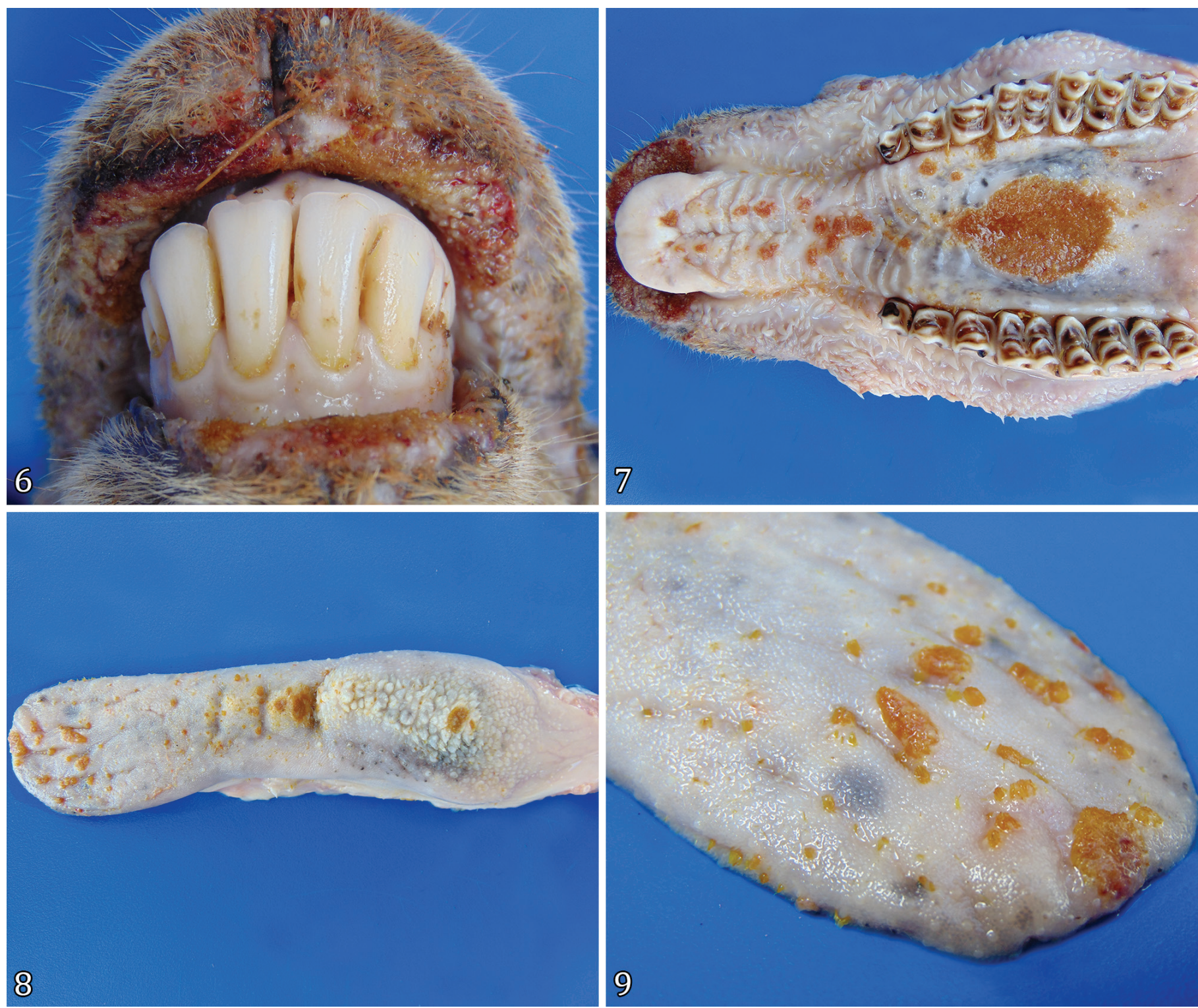

Fig.6-9. Macroscopic lesions in the digestive system of sheep that had ingested Tacinga inamoena. (6) Edematous and ulcerated upper and lower lips, (7) hard palate, and (8) tongue, showing multifocal to coalescent plaques measuring 0.5 to $5 \mathrm{~cm}$. These were elevated and firm and had an irregular ulcerated surface sometimes crusted with a yellow to light brown center with erythematous borders. (9) Tongue, showing ulcerative and proliferative multifocal to moderate coalescent glossitis. The ulcers are covered with yellow exudate and have hyperemic edges. The white arrows indicate adherent gloquids on the dorsal surface of the tongue. 
\& Keenan 1983). Furthermore, outbreaks of ocular lesions compatible with conjunctivitis caused by species of Andropogon, Elymus, and Hordeum have been described in alpacas in the United States of America (Fischer \& Hendrix 2012), and an outbreak of ophthalmic lesions in 49 cattle has been attributed to consumption of the seeds and flowers of Anisantha sterilis (Hudson et al. 2015). In Brazil, lesions have been reported in the labial commissure caused by the action of Panicum maximum leaves, a condition referred to as traumatic angular cheilitis (Barbosa et al. 2009a). Ulcerative lesions in the skin and oral cavity have also been observed in horses (Reis et al. 2011), cattle, and sheep (Barbosa et al. 2009b) subsequent to contact with the thorns of Mimosa pudica and Mimosa debilis.

Cacti have a widespread global distribution and can cause lesions similar to those detected in the cases described herein, and are generally associated with the spines and gloquids produced by these plants. In companion animals, such as cats and dogs, cacti have been found to cause ocular lesions compatible with keratoconjunctivitis after these animals had accessed areas colonized by large amounts of cacti (Dowler et al. 2019). In Kenya, the cactus Opuntia stricta has been found to cause ocular and severe gastrointestinal tract lesions in goats following contact and ingestion, leading to progressive weight loss. In these animals, gloquid lesions have also been reported in the abomasum (Ncebere et al. 2021). Cacti found in the semi-arid Northeast of Brazil have been associated with traumatic injuries in domestic animals, with species such as Cereous jamacaru (mandacaru) and Pilosocereus gounellei (xique-xique) known to cause hoof injuries in animals (Riet-
Correa et al. 2011); however, neither of these plants has been shown to be associated with either oral or ocular injuries.

In the outbreaks investigated in this study, the continuous access to T. inamoena prevented resolution of the ocular complications, despite the treatments performed by the producers, as the traumatic lesions were repeatedly made. However, having identified the problem, the ensuing treatment, which consisted of the removal of foreign bodies and topical antibiotic therapy, proved to be successful. which is similar to the efficacy of treatment described for herds of alpacas (Fischer \& Hendrix 2012) and cattle (Hudson et al. 2015). In this regard, antibiotic eye drops are particularly appropriate for treatment of lesions in the anterior segment of the eye and its anexa, given that despite their comparatively shorter half-life, these topically applied preparations achieve more adequate levels of therapeutic control than does systemic antimicrobial therapy (Gregory et al. 2015).

As a differential diagnosis of ocular lesions occurring in small ruminants, keratoconjunctivitis of infectious origin, such as that caused by Mycoplasma conjunctivae and Moraxella bovis, should always be considered due to the outbreak characteristics and the clinical signs presented (Gregory et al. 2015). However, in view of the presence of gloquids in the ocular structures and oral lesions, a possible infectious etiology was ruled out with respect to the present outbreaks.

Similarly, as an alternative diagnosis for oral lesions caused by T. inamoena. the possibility of ecthyma contagiosum should also be taken into consideration, particularly in the more severe cases, in which the lesions are not restricted to the mucocutaneous junctions, but also extend into the oral cavity. The different histopathological characteristics of the lesions make it possible

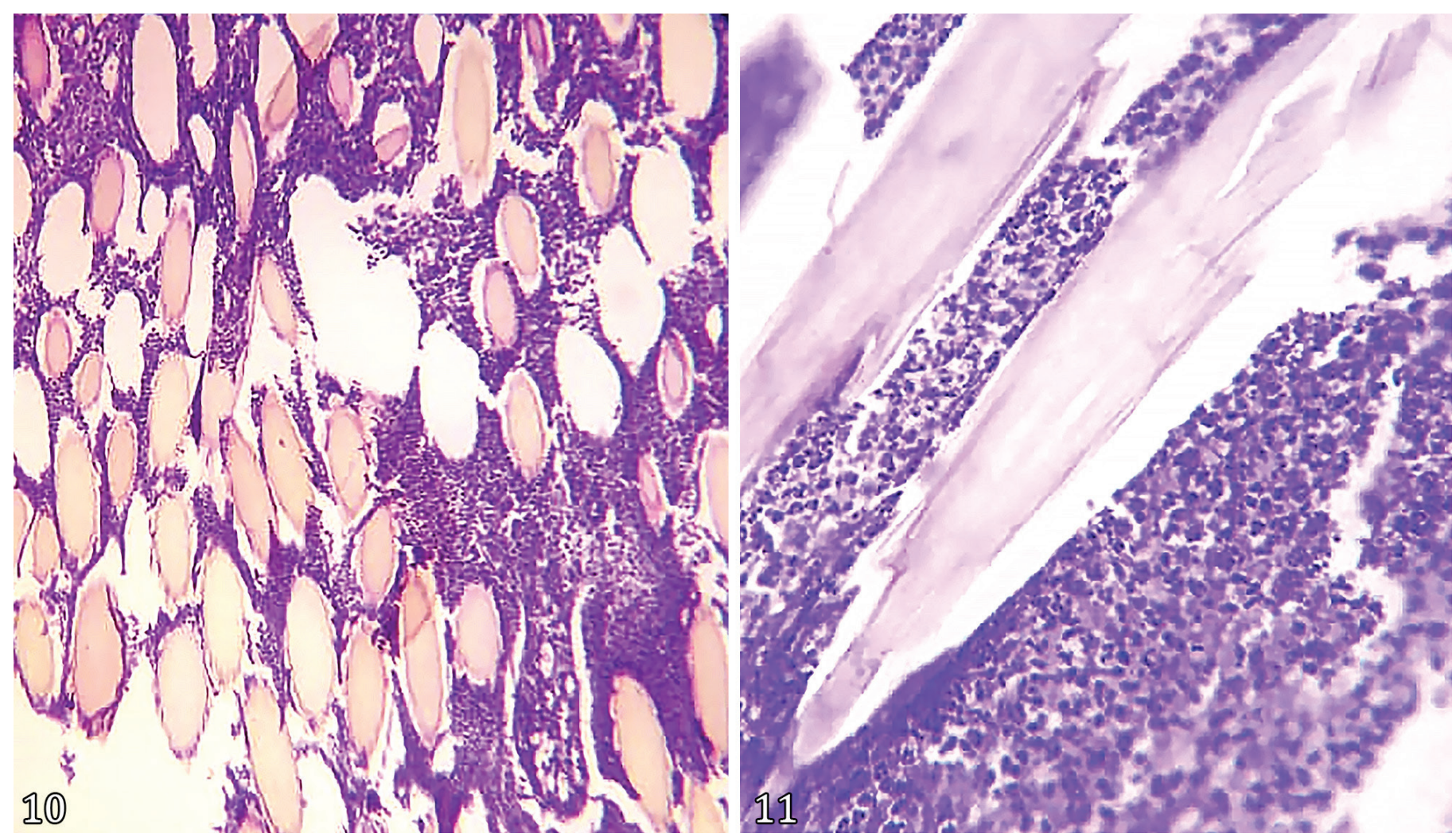

Fig.10-11. Traumatic stomatitis caused by Tacinga inamoena gloquids in sheep. (10) Presence of numerous gloquids in the submucosa, surrounded by an intense inflammatory infiltrate consisting predominantly of neutrophils. HE, obj.10x. (11) Magnified image showing details of gloquids amidst the neutrophils. HE, obj.40x. 
to establish a diagnosis. Ulcerative stomatitis, such as bluetongue and malignant catarrhal fever, and vesicular diseases, such as foot-and-mouth disease and vesicular stomatitis, should also be included among the differential diagnoses.

The almost exclusive presence of T. inamoena across large areas of the farms where the outbreaks occurred is clearly a cause of concern, as the loss of plant diversity tends to be indicative of the environmental degradation of these areas (Antogiovanni et al. 2020). The aforementioned similar oral and gastrointestinal tract lesions in goats identified in Kenya (Ncebere et al. 2021) occurred following invasion of grazing areas by 0 . stricta, a cactaceae in the same family as $T$. inamoena, and a similar circumstances may also characterize the semi-arid regions of Brazil.

Although it is evident that a resolution of this problem would necessitate the removal of animals from those areas colonized by T. inamoena, the lack of alternative suitable grazing areas, and the importance of cactaceae as sources of forage during periods of food shortage would tend to rule out this approach as a viable management option. T. inamoena is often the only seasonally available food for animals, as in the case of the two properties reported herein. The use of this cactaceae as animal feed in rural communities of the state of Paraíba (Machado et al. 2018) has previously been described, although here its periodically burned, which would probably contribute to eliminating the development of gloquids, or at least reduce their harmful effects. However, although the adoption of this practice could minimize the occurrence of outbreaks similar to those reported here, it would potentially cause other problems associated with the indiscriminate use of fire.

\section{CONCLUSION}

Tacinga inamoena causes serious oral and ophthalmic lesions in small ruminants grazed in the semi-arid northeastern region of Brazil, thereby contributing to potentially major economic losses. Moreover, this problem can be exacerbated by the invasive behavior of T. inamoena in areas undergoing environmental degradation.

Conflict of interest statement.- The authors declare that they have no conflicts of interest.

\section{REFERENCES}

Andrade L.D. 1989. Plantas das Caatingas. Brazilian Academy of Sciences, Rio de Janeiro, p.243.

Antogiovanni M., Venticinque E.M., Matsumoto M. \& Fonseca C.R. 2020. Chronic anthropogenic disturbance on Caatinga dry forest fragments. J. Appl. Ecol. 57(10):2064-2074. <https://dx.doi.org/10.1111/1365-2664.13686>

Barbosa J.D., Albernaz T.T., Riet-Correa G., Cerqueira V.D., Soares S.O., Campos K.F., Oliveira C.M.C. \& Duarte M.D. 2009a. Traumatic angular cheilitis in horses associated with ingestion of Panicum maximum. Pesq. Vet. Bras. 29(5):428-430.<https://dx.doi.org/10.1590/S0100-736X2009000500012>

Barbosa J.D., Silveira J.A.S., Albernaz T.T., Silva N.S.E., Reis A.S.B., Oliveira C.M.C., Riet-Correa G. \& Duarte M.D. 2009b. Skin lesions caused by the spines of Mimosa pudica (Leg. Mimosoideae) on the limbs of cattle and sheep in Pará state. Pesq. Vet. Bras. 29(5):435-438. <https://dx.doi.org/10.1590/ S0100-736X2009000500014>

Citi S., Mannucci T., Pedala F., Vannozzi I. \& Vignoli M. 2017. Acute pancreatitis associated with peritoneal migration of grass awn in two dogs. Acta Vet., Belgrade, 67(4):587-592. <https://dx.doi.org/10.1515/acve-2017-0048>
Coelho R.R.P., Justino P.L.A., Câmara A.P.C., Araújo L.F., Coelho T.J.S. \& Pereira F.C. 2020. Características tecnológicas de frutos do quipá (Tacinga inamoena) em 3 estádios de maturação. Braz. J. Anim. Environ. Res. 3(3):1388-1398. <https://dx.doi.org/10.34188/bjaerv3n3-056>

Dowler K.K., Scott E.M., Teixeira L.B.C. \& Vallone L.V. 2019. Cactus-induced keratoconjunctivitis in Texas: a case series of three dogs and one cat. Vet. Ophthalmol. 23(2):374-385. <https://dx.doi.org/10.1111/vop.12712>

Fischer K. \& Hendrix D. 2012. Conjunctivitis and ulcerative keratitis secondary to conjunctival plant foreign bodies in a herd of alpacas (Lama pacos). Vet. Ophthalmol. 15(2):110-114. <https://dx.doi. org/10.1111/j.1463-5224.2011.00939.X><PMid:22050866>

Gregory L., Safatle A.M.V., Antón J.J.R. \& Mayayo L.M.F. 2015. Exame Oftalmológico e Enfermidades Oculares em Pequenos Ruminantes. CLR Balieiro, São Paulo. 106p.

Hudson C.D., Higgins H.M. \& Huxley J.N. 2015. Ocular complications of barren brome exposure in a suckler herd. Vet. Rec. 159(12):388-389. <https:// dx.doi.org/10.1136/vr.159.12.388> <PMid:16980525>

Linon E., Geissbühler U., Karli P. \& Forterre F. 2014. Atlantoaxial epidural abscess secondary to grass awn migration in a dog. Vet. Comp. Orthop. Traumatol. 27(2):155-158. <https://dx.doi.org/10.3415/VCOT-13-07-0095> $<$ PMid:24493255>

Lucena C.M., Costa G.G.S., Carvalho T.K.N., Guerra N.M., Quirino Z.G.M. \& Lucena R.F.P. 2012. Uso e conhecimento de cactáceas no município de são mamede (Paraíba, Nordeste do Brasil). Revta Biol. Farm. Volume especial:121-134.

Machado J.S., Lucena C.M., Santos S.S., Ferreira E.C., Nunes G.M. \& Lucena R.F 2018. Conhecimento botânico local sobre cactáceas: um estudo de caso no município de boqueirão, Paraíba, Nordeste do Brasil. Flovet 1(10):1-21.

McCosker J.E. \& Keenan D.M. 1983. Ulcerative stomatitis in horses and cattle caused by triticale hay. Aust. Vet. J. 60(8):259. <https://dx.doi. org/10.1111/j.1751-0813.1983.tb05986.X><PMid:6639534>

Ncebere J.M., Mbuthia P.G., Waruiru R.M. \& Gathumbi P.K. 2021. Gross and histopathology of goats feeding on Opuntia stricta in Laikipia County, Kenya. Vet. Med. Int. 2021:1-12. <https://dx.doi.org/10.1155/2021/8831996>

Reis A.S.B., Duarte M.D., Sousa M.G.S., Freitas N.F.Q.R., Yamasaki E.M., Silva A.G.M., Oliveira C.M.C. \& Barbosa J.D. 2011. Traumatic skin injuries caused by the thorns of Mimosa pudica and Mimosa debilis in equidae. Pesq. Vet. Bras. 31(9):768-772.<https://dx.doi.org/10.1590/S0100-736X2011000900008>

Riet-Correa B., Riet-Correa G. \& Riet-Correa F. 2011. Plants causing mechanical or traumatic alterations in ruminants and horses, with emphasis on Stipa spp. (Gramineae). Pesq. Vet. Bras. 31(6):516-520. <https://dx.doi. org/10.1590/S0100-736X2011000600010>

Sinopidis X., Fouzas S., Ginopoulou A., Pantiora A., Mantagos S., Papanastasiou D. \& Salakos C. 2011. Foreign body migration through the parotid duct causing suppurative parotitis. Int. J. Ped. Otorhinolaryngol. 6(2):87-88. <https://dx.doi.org/10.1016/j.pedex.2010.04.001>

Sorden S.D. \& Radostits 0.M. 1996. Lingual arteritis, multifocal meningoencephalitis, and uveitis induced by barley spikelet clusters in a two-year-old heifer. Can. Vet. J. 37(4):227-229. <PMid:8801018>

Souza A.C.M., Gamarra-Rojas G., Andrade S.A.C. \& Guerra N.B. 2007. Physical, chemical and organoleptic characteristics of quipá (Tacinga inamoena, Cactaceae). Revta Bras. Frutic. 29(2):292-295. <https://dx.doi.org/10.1590/ S0100-29452007000200020>

Taylor N. \& Zappi D. 2004. Cacti of Eastern Brazil. Royal Botanic Gardens, Kew. 644p.

Thiverge G. 1973. Granular stomatitis in dogs due to burdock. Can. Vet. J. 14(4):96-97. <PMid:4699613>

Turnquist S.E., Ostlund E.N., Kreeger J.M. \& Turk J.R. 2001. Foxtail-induced ulcerative stomatitis outbreak in a Missouri stable. J. Vet. Diagn. Invest. 13(3):238-240. <https://dx.doi.org/10.1177/104063870101300308> $<$ PMid:11482601>

Zappi D., Taylor N., Santos M.R. \& Larocca J. 2015 Cactaceae. Lista de Espécies da Flora do Brasil, Jardim Botânico do Rio de Janeiro, Rio de Janeiro. 